\title{
APLIKASI ELEKTRODE GLASSY CARBON DIMODIFIKASI NANOPARTIKEL EMAS TERHADAP PENENTUAN Cr(III) DENGAN PENGARUH Fe(III), Mn(II), Co(II) DAN Ni(II) SECARA VOLTAMMETRI
}

\author{
S. Wyantuti", I. F. Sukmana, D. Rakhmawaty, dan Y. W. Hartati \\ "Departemen Kimia FMIPA Universitas Padjadjaran, Jl. Raya Bandung-Sumedang km 21 \\ Jatinangor Sumedang, Jawa Barat \\ *Email: santhy.wyantuti@unpad.ac.id
}

\begin{abstract}
ABSTRAK
Kromium banyak digunakan dalam bidang industri, akibatnya limbah dari senyawa kromium tersebut juga banyak tercipta baik di udara, tanah maupun air. $\mathrm{Cr}$ (III) diperlukan dalam jumlah kecil dalam membantu insulin dalam menormalkan jumlah glukosa dan kolesterol dan bermanfaat pada metabolisme lemak . Kekurangan $\mathrm{Cr}(\mathrm{III})$ dapat menyebabkan penyakit yang disebut penyakit kekurangan kromium (chromium deficiency). Untuk itu diperlukan suatu metode yang sensitif dan efektif untuk menganalisis kromium. Metode voltammetri merupakan metode yang menjanjikan, karena dapat menggunakan elektrode kerja yang bisa secara luas dimodifikasi. Penelitian ini bertujuan untuk mempelajari pengaruh ion $\mathrm{Fe}(\mathrm{III}), \mathrm{Mn}(\mathrm{II}), \mathrm{Co}$ (II) dan $\mathrm{Ni}$ (II) pada analisis kromium, serta mengetahui akurasi, presisi, dan limit deteksi dari penentuan $\mathrm{Cr}$ (III) secara volltammetri pulsa differensial. Prosedur yang akan dilakukan adalah pembuatan larutan-larutan, pembuatan koloid nanopartikel emas, modifikasi GCE, optimasi scan rate, deteksi pengaruh ion besi(II), mangan(II), kobalt(II) dan $\mathrm{Ni}$ (II) pada pengukuran $\mathrm{Cr}$ (III) serta deteksi $\mathrm{Cr}$ (III) dalam limbah elektroplating secara voltammetri menggunakan elektroda glassy carbon nanopartikel emas. Hasil dari penelitian menunjukkan bahwa Ion $\mathrm{Fe}(\mathrm{III}), \mathrm{Mn}(\mathrm{II}), \mathrm{Co}(\mathrm{II})$ dan $\mathrm{Ni}(\mathrm{II})$ terbukti mempengaruhi tinggi arus $\mathrm{Cr}(\mathrm{III})$. Akurasi pengukuran sebesar 96,17\%, presisi sebesar 98,19\% dan limit deteksi sebesar 4,6889 ppm. Konsentrasi Cr(III) dalam limbah elektroplating dapat ditentukan dengan metode standar adisi yaitu sebesar 60,072 ppm.
\end{abstract}

Kata kunci: elektrode glassy karbon, kromium(III), nanopartikel emas, pengaruh ion logam lain, voltammetri,

\begin{abstract}
Chromium is widely used in industry, producing waste in the air, soil and water. Chromium (III) is required in small amounts to help insulin normalize the amount of glucose and cholesterol as well as in fat metabolism. Deficiency of chromium (III) can cause a disease called chromium deficiency. Hence, a sensitive and effective method for analyzing chromium was required. Voltammetry method is a promising method, because the working electrode can be widely modified. This study aims to investigate the effect of Fe (III), Mn (II), Co (II) and $\mathrm{Ni}$ (II) metal ions to chromium analysis, and to determine accuracy, precision, and detection limit of the determination of $\mathrm{Cr}$ (III) using differential pulse volltammetri. The procedures are preparation of the solutions, preparation of colloidal gold nanoparticles, modification of GCE, optimization scan rate, detection of effect of iron ions (II), manganese (II), cobalt (II) and Ni (II) to Cr (III) analysis as well as detection of Cr (III) in electroplating waste by voltammetry using a glassy carbon electrode modified by gold nanoparticles. The results of the study showed that the Fe (III), Mn (II), Co (II) and Ni (II) ions affect the current high of Cr (III). The accuracy measurement is $96.17 \%$, with precision of $98.19 \%$ and a detection limit of 4.6889 ppm. The concentration of $\mathrm{Cr}$ (III) in electroplating which determined with standard addition method was 60.072 ppm.
\end{abstract}

Keywords: Chromium(III), foreign metal ions effect, glassy carbon electrode, gold nanoparticles voltammetry

\section{PENDAHULUAN}

Kromium di udara bereaksi dengan oksigen menghasilkan $\mathrm{Cr}_{2} \mathrm{O}_{3}$ yang memiliki sifat non pori sehingga banyak dimanfaatkan dalam industri seperti elektroplating, penyamakan kulit, pewarnaan cat dan tekstil. Akibatnya limbah kromium banyak terdapat di alam. $\mathrm{Cr}$ (III) lebih efektif dari Cr(VI) dalam menyebabkan genotoxicity dalam sistem sel bebas (Welch et al., 2004). Kromium trivalen (Cr(III) atau $\mathrm{Cr}^{3+}$ ) apabila masuk ke dalam tubuh manusia melebihi batas yang ditentukan maka akan menyebabkan kerusakan pada sistem pencernaan serta pada sistem 
pernapasan (Saha dkk., 2012, Li dan Kim, 2009). Oleh karena itu deteksi Cr(III) perlu dilakukan.

Pada limbah elektroplating $\mathrm{Cr}(\mathrm{III})$ dan (VI) merupakan konstituen utama $( \pm 90 \%)$ sisanya adalah $\mathrm{Fe}, \mathrm{Mn}, \mathrm{Co}$, dan $\mathrm{Ni}(10 \%)$ ). Air limbah yang tercemar merupakan racun yang berbahaya bagi kehidupan organisme. Pada limbah terdapat ion logam lain oleh karena itu diperlukan suatu metode yang dapat menganalisis $\mathrm{Cr}$ (III) dengan adanya pengaruh ion logam lain. Dilihat dari harga potensial standarnya $\mathrm{Fe}(\mathrm{III}), \mathrm{Mn}(\mathrm{II}), \mathrm{Co}(\mathrm{II})$, dan $\mathrm{Ni}(\mathrm{II})$ memiliki nilai yang tidak jauh berbeda dengan $\mathrm{Cr}$ (III). Harga potensial $\mathrm{Cr}$ (III) sebesar $-0,74$ $\mathrm{V}, \mathrm{Fe}(\mathrm{III})$ sebesar +0,76 V, Mn(II) sebesar $1,18 \mathrm{~V}, \mathrm{Co}(\mathrm{II})$ sebesar $-0,28 \mathrm{~V}$ dan $\mathrm{Ni}(\mathrm{II})$ sebesar $0,25 \mathrm{~V}$. Sifat elektrokimia dan ukuran ionik yang mirip dari suatu ion logam dengan ion logam lainnya dapat mengganggu pengukuran ion logam tersebut (Wong, 2011). Banyak metode sensitif yang telah digunakan untuk penentuan kromium seperti (AAS) (Kiran et al., 2008) LD=0,13 $\mu \mathrm{g} / \mathrm{L}$, ICP-MS $\mathrm{LD}=0,81 \mu \mathrm{g} / \mathrm{L}$, kromatografi $\mathrm{LD}=0,18 \mu \mathrm{g} / \mathrm{L}$ namun ketiga metode ini hanya dapat menghasilkan informasi mengenai konsentrasi kromium total (Liu, 2008). Oleh karena itu, metode elektrokimia telah diterapkan untuk penentuan $\mathrm{Cr}$ (III).

Analisis kromium dengan menggunakan metode elektrokimia terus mengalami perkembangan seiiring meningkatnya jenis kebutuhan pengukuran (Saha dkk, 2012; Hong dkk, 2012; Jin dkk, 2014). Perkembangan ini menghasilkan berbagai modifikasi pada elektrode kerja, salah satunya adalah elektrode berbasis karbon, yang kemudian dapat diaplikasikan untuk keperluan analisis (Bui dkk, 2012; Dai dkk, 2006). Pada penelitian sebelumnya telah dilakukan pendeteksian $\mathrm{Cr}(\mathrm{III})$ yang menggunakan elektrode glassy carbon dimodifikasi menggunakan nanopartikel emas, sebab nanopartikel emas dapat mendeteksi $\mathrm{Cr}$ (III) dengan baik, juga cara pembuatannya yang lebih sederhana dibanding karbon nanotube. Selain itu telah dilakukan optimasi waktu dan potensial deposisi yang meningkatkan sensitifitas pendeteksian $\mathrm{Cr}(\mathrm{III})$ (Wyantuti, 2017).

Penelitian ini mempelajari pengaruh ion $\mathrm{Fe}$ (III), Mn(II), Co(II) dan Ni(II) pada analisis Cr(III) untuk meningkatkan sensitifitas pendeteksian $\mathrm{Cr}$ (III) menggunakan EGC66
AuNP secara voltammetri pulsa differensial, serta mengaplikasikannya dalam limbah elektroplating.

\section{MATERI DAN METODE}

\section{Bahan}

Akuabides (PT. Ikapharmindo putramas), Ammonium hidroksida (Merck), Asam asetat (Merck), Asam klorida 37\% (Merck), Asam Nitrat, Besi(III) nitrat, Etanol (Redest), Emas 99,99\%, Kalium Klorida (Merck), Kobalt(II) nitrat, Mangan(II)nitrat, Natrium sitrat (Merck), Natrium asetat (Aldrich), Natrium borohidrat (Aldrich), Nikel(II) nitrat. Limbah electroplating yang didapat dari UTC Aeronautical System.

\section{Peralatan}

Alat yang digunakan dalam penelitian ini adalah elektrode glassy karbon (EDAQ), potensiostat (Metrohm ${ }^{\circledR} \mu$ Autolab type III) 757 VA, magnetic stirer, pipet mikro 20-100 $\mu \mathrm{L}$ (Ependorf), spektoskopi UV-Vis (Thermo scientific) dan ultrasonic.

\section{CARA KERJA}

\section{Pengukuran Voltammetri Menggunakan Elektrode Modifikasi}

Mula-mula dilakukan optimasi scan rate kemudian dilakukan pengukuran kromium(III) dengan berbagai konsentrasi pada kondisi optimum sehingga menghasilkan voltammogram yang diolah menjadi kurva baku dan parameter analitiknya.

\section{Penentuan sinyal kromium(III) terhadap ion logam $\mathrm{Fe}$ (III), Mn(II), Co(II) dan Ni(II) pada kondisi optimum}

Sebanyak $3 \mathrm{~mL}$ larutan $\mathrm{Cr}(\mathrm{III}) 10 \mathrm{ppm}$, buffer asetat $0,50 \mathrm{M} \mathrm{pH} \mathrm{5,0} \mathrm{dan} \mathrm{Fe(III)} 10$ ppm dimasukkan dalam sel voltammetri lalu alat dirangkai seperti gambar rangkaian alat, dilakukan pada waktu dan potensial pretreatment pada kondisi optimum. Potensial deposisi diatur pada $-1,50 \mathrm{~V}$ dengan waktu deposisi 90 detik dengan scan rate $0,05 \mathrm{~V} / \mathrm{s}$ dan modulasi amplitudo $0,05 \mathrm{~V}$ dengan rentang potensial sinyal reduksi dilakukan pada rentang potensial $-1,50 \mathrm{~V}$ sampai $1,50 \mathrm{~V}$. Prosedur sama untuk penambahan $\mathrm{Mn}$ (II), $\mathrm{Co}($ II) dan $\mathrm{Ni}(\mathrm{II})$. 


\section{Penentuan sinyal Cr(III) dalam limbah pelapisan baja}

Larutan $\mathrm{Cr}(\mathrm{III})$ variasi penambahan volume $\mathrm{Cr}$ (III) 40 ppm $1 \mathrm{~mL}$ dan $2 \mathrm{~mL}$; dimasukan dalam sel voltammetri kemudian ditambahkan larutan buffer asetat $\mathrm{pH}$ 5,0 dan limbah pelapisan baja lalu alat dirangkai. Potensial deposisi dilakukan pada potensial deposisi $-1,5 \mathrm{~V}$, waktu deposisi 90 detik dengan scan rate optimum dan modulasi amplitudo optimum, rentang potensial sinyal reduksi dilakukan pada rentang potensial $-1,5$ V sampai $+1,5 \mathrm{~V}$.

\section{HASIL DAN PEMBAHASAN}

\section{Pengukuran Voltammetri Menggunakan Elektrode Modifikasi}

Scan rate adalah kecepatan pemindaian yang diberikan untuk mereduksi $\mathrm{Cr}$ (III) pada larutan menjadi $\mathrm{Cr}(0)$ pada permukaan elektrode. Penentuan scan rate optimum dilakukan dengan memvariasikan scan rate pada 0,$03 ; 0,04 ; 0,05 ; 0,06$; dan $0,07 \mathrm{~V} / \mathrm{s}$ secara DPV dengan rentang potensial $-1,5 \mathrm{~V}$ sampai $+1,5 \mathrm{~V}$ potensial deposisi $-1,5 \mathrm{~V}$ waktu deposisi 90 detik, dan modulasi amplitude 0,05 V. Hasil voltamogram ditunjukkan pada Gambar 1.

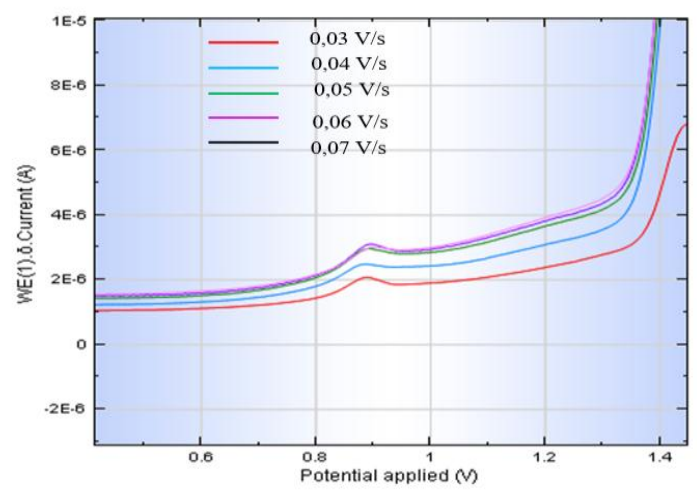

Gambar 1. Voltammogram variasi scan rate pada larutan $\mathrm{Cr}$ (III) 5 ppm dengan potensial deposisi $-1,5 \mathrm{~V}$ waktu deposisi 90 detik, dan modulasi amplitude $0,05 \mathrm{~V}$

Gambar 1. menunjukkan bahwa scan rate berpengaruh terhadap tinggi arus puncak semakin cepat scan rate yang maka arus yang dihasilkan akan semakin besar, namun terjadi penurunan arus pada scan rate 0,06 dan 0,07 $\mathrm{V} / \mathrm{s}$ karena kecepatan scan terlalu cepat, sehingga $\mathrm{Cr}$ (III) yang terdapat dalam analit belum seluruhnya terpindai. Maka dapat disimpulkan bahwa scan rate $0,05 \mathrm{~V} / \mathrm{s}$ merupakan laju optimum untuk analisis $\mathrm{Cr}(\mathrm{III})$.

\section{Penentuan rentang konsentrasi linier Cr(III)}

Daerah konsentrasi linier GCE yang dimodifikasi AuNP untuk analisis $\mathrm{Cr}$ (III) dipelajari untuk mengetahui daerah konsentrasi yang memberikan daerah linier antara tinggi puncak arus dengan konsentrasi $\mathrm{Cr}(\mathrm{III})$. Voltammogram variasi konsentrasi Cr(III) ditunjukkan pada Gambar 2.

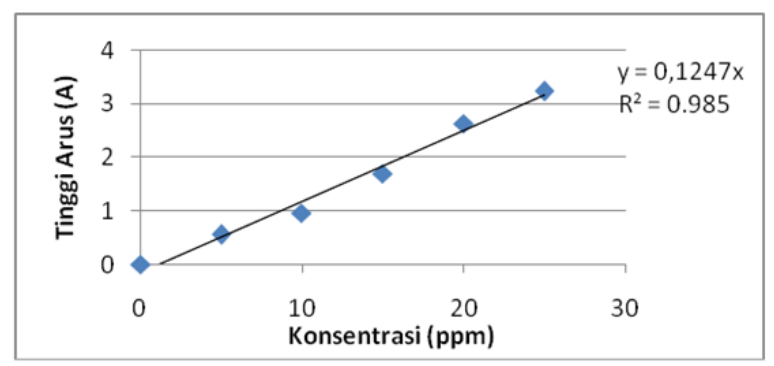

Gambar 2. Kurva kalibrasi dari $\mathrm{Cr}(\mathrm{III})$ dengan waktu deposisi: 90 detik; potensial deposisi: $-1,50$ $\mathrm{V}$; scan rate $0,05 \mathrm{mV} /$ detik; modulasi amplitudo $0,05 \mathrm{~V}$

Gambar 2 menunjukkan rentang konsentrasi yang memberikan hubungan yang linier terhadap tinggi arus puncak $\mathrm{Cr}(\mathrm{III})$. Persamaan korelasi yang diperoleh adalah $\mathrm{y}=0,1247 \mathrm{x}$ dengan regresi linier sebesar 0,9850. Dibawah kondisi optimal puncak arus yang linier dengan rentang konsentrasi $\mathrm{Cr}$ (III) $5-25$ ppm diperoleh batas deteksi sebesar 4,6889 ppm dengan standar deviasi sebesar 0,1949 akurasi sebesar $96,17 \%$ dan presisi 98,19\%. Hasil ini menunjukkan bahwa ketepatan pengukuran dari metode ini cukup baik untuk penentuan Cr(III).

\section{Pengaruh Penambahan Ion Logam Lain dalam Analisis Cr(III) \\ Pada penentuan $\mathrm{Cr}(\mathrm{III})$ secara DPV} adanya gangguan dari logam-logam lain diteliti dengan penambahan ion zat penggangu. Data hasil pengukuran ditunjukkan pada Tabel 1. 
Tabel 1. Hasil pengukuran Cr(III) yang ditambahkan ion pengganggu

\begin{tabular}{|c|c|c|c|c|c|}
\hline \multirow[t]{2}{*}{$\begin{array}{c}\text { Ion } \\
\text { Pengganggu }\end{array}$} & \multicolumn{2}{|c|}{$\begin{array}{c}\mathrm{Cr}(\mathrm{III}) 10 \mathrm{ppm} \text { tanpa } \\
\text { penggangu }\end{array}$} & \multicolumn{2}{|c|}{$\begin{array}{l}\mathrm{Cr}(\mathrm{III}) 10 \mathrm{ppm} \text { ditambah } \\
\text { ion pengganggu } 10 \mathrm{ppm}\end{array}$} & \multirow[t]{2}{*}{$\begin{array}{c}\text { Perubahan } \\
(\%)\end{array}$} \\
\hline & $\begin{array}{l}\text { Potensial } \\
\text { (V) }\end{array}$ & $\begin{array}{l}\text { Arus } \\
(\mu \mathrm{A})\end{array}$ & $\begin{array}{l}\text { Potensial } \\
\text { (V) }\end{array}$ & $\begin{array}{l}\text { Arus } \\
(\mu \mathrm{A})\end{array}$ & \\
\hline $\mathrm{Fe}(\mathrm{III})$ & 0,8902 & 0,9442 & 0,8920 & 0,3200 & 66,1074 \\
\hline Mn(II) & 0,8902 & 0,9442 & 0,8566 & 3,5443 & 58,8000 \\
\hline Co(II) & 0,8902 & 0,9442 & 0,9699 & 0,3890 & 88,1987 \\
\hline $\mathrm{Ni}(\mathrm{II})$ & 0,8902 & 0,9442 & - & - & \\
\hline
\end{tabular}

Hasil pengukuran menunjukkan bahwa adanya ion logam $\mathrm{Fe}(\mathrm{III}), \mathrm{Mn}(\mathrm{II}), \mathrm{Co}(\mathrm{II})$, dan $\mathrm{Ni}$ (II) terbukti mengganggu pengukuran arus $\mathrm{Cr}(\mathrm{III})$. Ion $\mathrm{Fe}(\mathrm{III}), \mathrm{Co}(\mathrm{II})$, dan Ni(II) memiliki potensial reduksi yang tidak jauh berbeda dan lebih positif dibandingkan dengan logam $\mathrm{Cr}(\mathrm{III})$, sehingga saat diberi potensial $-1,5 \mathrm{~V}$ ion-ion pengganggu tersebut ikut tereduksi, dan menyebabkan jumlah kromium yang tereduksi berkurang dari semestinya. Oleh sebab itu puncak arus $\mathrm{Cr}$ (III) menurun. Sedangkan Mn(II) memiliki potensial reduksi yang lebih negatif dan berdekatan dengan $\mathrm{Cr}$ (III), saat diberi potensial reduksi, $\mathrm{Cr}$ (III) akan tereduksi terlebih dahulu, dan diikuti reduksi dari $\mathrm{Mn}(\mathrm{II})$, puncak reduksi $\mathrm{Cr}$ (III) dan $\mathrm{Mn}(\mathrm{II})$ berhimpitan dan terjadi overlapping sehingga puncak arus menjadi lebih tinggi, dan konsentrasi $\mathrm{Cr}$ (III) yang terukur pun menjadi lebih tinggi. Selain itu ukuran ionik yang mirip pun menyebabkan terjadinya gangguan.

\section{Analisis sampel limbah elektroplating}

Penentuan kadar $\mathrm{Cr}$ (III) dalam limbah elekroplating dilakukan secara voltammetri pulsa differensial dengan metode adisi standar karena mampu meminimalkan kesalahan yang disebabkan oleh perbedaan kondisi lingkungan (matriks) sampel dan standar . Idealnya kalibrasi standar seharusnya mendekati komposisi dari sampel yang dianalisis, tidak hanya pada konsentrasi analit tetapi juga dalam hal konsentrasi dari elemen lain yang ada dalam matriks sampel, sehingga dapat meminimalkan pengaruh dari berbagai komponen dalam sampel terhadap sinyal yang terukur (Skoog, 1996). Dari hasil pengukuran didapat kurva adisi standar seperti yang ditunjukkan pada Gambar 3.

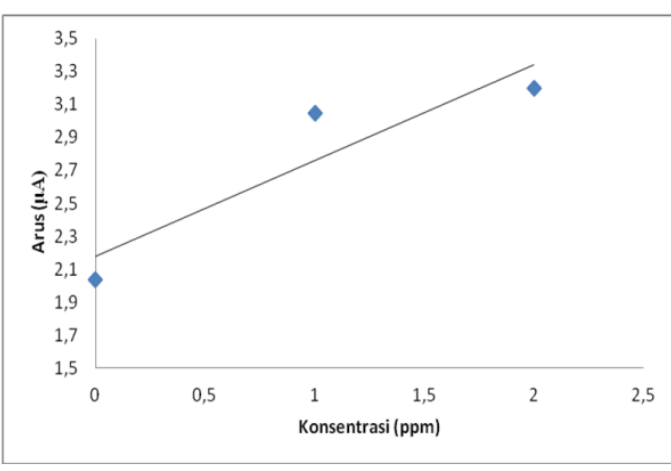

Gambar 3. Kurva adisi standar pada limbah dengan kondisi pengukuran $\mathrm{Cr}$ (III) optimum

Hasil perhitungan didapat konsentrasi $\mathrm{Cr}$ (III) dalam limbah elektroplating sebesar 60,072 ppm.

\section{SIMPULAN}

\section{Simpulan}

Hasil penelitian yang telah dilakukan, diperoleh simpulan sebagai berikut:

1. Scan rate optimum dalam analisis $\mathrm{Cr}$ (III) dengan menggunakan electrode glassy carbon yang dimodifikasi AuNP secara voltammetri pulsa differensial aadalah $0,05 \mathrm{~V}$ dengan limit deteksi 4,6889 ppm presisi pengukuran $98,19 \%$ serta akurasi sebesar 96,17\%.

2. Adanya penambahan ion $\mathrm{Fe}(\mathrm{III}), \mathrm{Mn}(\mathrm{II})$, $\mathrm{Co}(\mathrm{II})$ dan $\mathrm{Ni}$ (II) pada pengukuran $\mathrm{Cr}$ (III) terbukti mengganggu arus puncak $\mathrm{Cr}(\mathrm{III})$.

3. Konsentrasi Cr(III) dalam limbah elektroplating dapat diketahui dengan menggunakan metode adisi standar yaitu 60,072 ppm.

\section{UCAPAN TERIMAKASIH}

Penulis mengucapkan terima kasih kepada Universitas Padjadjaran atas pendanaan penelitian Hibah Kompetitif juga kepada Lembaga Penelitian dan Pengabdian Masyarakat Universitas Padjajdaran. 


\section{DAFTAR PUSTAKA}

Bui, M. N., C.A. Li, K.N. Han, X. Pham, G.H. Seong, 2012, Simultaneous detection of ultratrace lead and copper with gold nanoparticles patterned on carbon nanotube thin film, Analyst. 137:188894.

Dai, X., R.G. Compton, 2006, Direct electrodeposition of gold nanoparticles onto indium tin oxide film coated glass: Application to the detection of arsenic(III), Anal. Sci., 22:567-70.

Hong, J., W. Wang, K. Huang, W.-Y. Yang, Y.-X. Zhao, B.-L. Xiao. 2012. A highly efficient nano-cluster artificial peroxidase and its direct electrochemistry on a nano complex modified glassy carbon electrode. Anal. Sci. 28:711-6.

Jin, W., G. Wu, A. Chen, 2014, Sensitive and selective electrochemical detection of chromium (VI) based on gold nanoparticle-decorated titania nanotube arrays. Analyst. 139:235-41.

Kiran, K. S. Kumar, B. Prasad, K. Suvardhan, R.B. Lekkala, K. Janardhanam, 2008, Speciation determination of chromium(III) and (VI) using preconcentration cloud point extraction with flame atomic absorption spectrometry (FAAS), $J$. Hazard. Mater, 150:582-6.

Liu, B., Lu Liyuan, Wang Min and Zi Yanqin, 2008, A study of nanostructured gold modified glassy carbon electrode for the determination of trace $\mathrm{Cr}(\mathrm{VI})$. Departement of Chemistry Huaibei Coal Normal College. Huaibei.
Ly, S. Y. and M. J. Kim, 2009, Diagnostic assay of chromium(VI) in the ex vivo fluid of the urine of a smoker using a fluorine-doped handmade sensor, Journal of Clinical Laboratory Analysis, 23:82-87.

Miller, J. C. and J. N. Miller, 2000, Statistic and chemometric for analytical chemistry, 4th edition, New York:Ellis Hardwood.

Skoog, D. A., D. M. West, F.J. Holler, 1996, Fundamental of analytical chemistry. 5th edition, Canada:thomson Brooks.

Saha, K., S. S. Agasti, C. Kim, X. Li, V.M. Rotello, 2012, Gold nanoparticles in chemical and biological sensing. Chem. Rev., 112:2739- 2779.

Wang, J., 2000, Analytical electrochemistry. Second Edition. New York:Wiley$\mathrm{VCH}$.

Wong, Pooi See, Sheila Nathan, Lee Yook Heng, 2011, A Disposable Copper (II) Ion Biosensor Based on SelfAssembly of L- Cysteine on Gold Nanoparticle-Modified Screen-Printed Carbon Electrode, Journal of Sensors. Article ID 230535.

Welch, C.N., M. E. Hyde, O. Nekrassova and R. G. Compton, 2004, The Oxidation of Trivalent Chromium at Polycrystalline Gold Electrodes. Phys. Chem. Chem. Phys. 6:3153-3159.

Wyantuti, S., R. A. Fadhilah, D. Rakhmawaty, Y. W. Hartati, 2017, Preparasi Elektrode Glassy Carbon-AuNP dan Aplikasinya terhadap Penentuan $\mathrm{Cr}(\mathrm{III})$ dengan Pengaruh $\mathrm{Cd}(\mathrm{II})$, $\mathrm{Cu}(\mathrm{II}), \quad \mathrm{Zn}(\mathrm{II})$ dan $\mathrm{Cr}(\mathrm{VI})$ secara Voltammetri. Journal Chimica et Natura Acta. 5 : 53-59. 